\title{
Comparative Performance of Bovans Nera (Rhode Black) and other Commercial Pullet Strains
}

\author{
James Ien-oa IMOUOKHOME ${ }^{1}$, Osaihiomwan OJOGHO \\ ${ }^{1}$ Benson Idahosa University, Faculty of Agriculture and Agricultural Technology, Department of Animal Science, Ugbor, Edo State, Nigeria \\ ${ }^{2}$ Benson Idahosa University, Faculty of Agriculture and Agricultural Technology, Department of Agricultural Economics \\ and Extension Services, Ugbor, Edo State, Nigeria; igomercy@yahoo.com ("corresponding author)
}

\begin{abstract}
The present study examined the comparative performance between Bovans Nera and other commercial pullet strains in Nigeria. This study was carried out in the pullet house at the Teaching and Research Farm of the University of Ibadan, Ibadan, Nigeria, from January to April, 2002. The experiment was carried out to compare the growth performance and profitability of Bovans Nera with three other commercial pullet strains, Bovans Godline, Lohmann White and Lohmann Tradition. All data collected were subjected to the analysis of variance using the SAS General Linear Model procedure. Differences between treatment means were separated using Duncans New Multiple Range Test. Profitability was assessed using net returns by subtracting costs (rearing pullet, feed and packaging excluding overheads and labour) from income (from egg sales and spent birds). The results showed that Bovans Nera was better in feed conversion ratio, feed efficiency (a greater weight gain per unit feed intake) and attained a greater weight and a better market value than the other pullet strains. There was a higher production cost for Bovans Nera when compared with other strains. However, Bovans Nera will give more returns on investment even when their eggs are translated to monetary terms. These differences can be attributed to variation in the genetic constitution of individual strains.
\end{abstract}

Keywords: ANOVA, poultry, profit, pullet, strain

\section{Introduction}

The importance of poultry production to the biological needs, economic and social development of the people in any nation cannot be overemphasized. Oluyemi and Roberts (1979) claimed that poultry production in Nigeria as well as other warm climate countries has a high priority rating compared with other types of livestock because poultry has better energy and protein conversion ratio and that net return on investment are relatively high.

Commercial layer strains produce eggs for food and egg processing industries. Egg consumption on regular basis can effectively correct nutritional imbalance among vulnerable group particularly nursing mothers and children (Olawumi et al., 2006).

Apart from these, poultry product most especially eggs and meats (broilers) are good sources of animal protein. Poultry production has been identified as a means of ensuring sustainable family income. Poultry can be established with minimum capital, and as a side-project (Sani et al., 2000).

Moreover, they can fend for themselves on free-range without much care (Umeh and Odo, 2002).

In egg-producing farms, day-old chicks are purchased from specialized hatcheries that produce egg-producing pullets. These pullets are either raised by the egg producer or a pullet grower until they are ready to start laying eggs, which is usually at 19 weeks of age (Beutler, 2007). Laying hens in egg producing farms are usually of small body frame and body weight compared to broilers. Egg producing chicken breeds have been bred and raised for maximum egg production (up to 300 eggs per year) rather than high meat yield (Beutler, 2007).

The black and brown plumage (feather colour) layer strains varied in their productive capability and live ability in this hot climate.

Olawumi (2007) reported that parents of black layer strain had lower mortality rate and more adaptable to hot weather than parents of brown layer strain. The production potential of a good layer strain is better assessed based on the number and size of eggs produced during its lifetime and its final as spent-hen. The cost of day-old chicks, equipment, feeds, drugs and other inputs are unbearable and for a farmer to succeed in this enterprise, the most productive layer strain must be reared on the farm in order to achieve the desired maximum profit, repay the loans secured for the business and plan for expansion.

In the poultry business, farmers are quick to implicate feed when problems arise in their farms since feed constitutes over $70 \%$ of the costs of production according to Toluen and Igba (2007), Akinmutimi (2003). In many occasions, the problems may not emanate from the feed. 
22

Several factors may be responsible for poor performance in a flock. These may include poor handling practices, poor water quality, poor litter management, irregular feeding intervals, poor health of the birds, poor sanitation in the poultry house and environment and poor supervision of staff among other factors (Abeke et al., 2003; Oladunjoye et al., 2005). Most important, but scarcely considered, is the strain of bird for production.

Agbamu (2005) reported that poultry business is a profitable venture provided improved strains are stocked.

A high level performance, no doubt, is the aim of any enterprise involved in the production of eggs. Genetic variation in egg production between breeds, strains and lines has been reported (Hocking et al., 2003; Nawar and Abdou, 1999; Suk and Park, 2001). Pullet quality is the foundation for optimum layer performance. The genetic potential for the production and profit stream arrives on day one with the chick. Advances in genetic selection are delivering lighter body weight targets, earlier ages to $50 \%$ production, and higher hen day rates with better persistency, all on lower feed intakes. This is certainly a good formula for higher profits, but this also comes with increased pressure for the best pullet possible. Besides, monitoring the growth, production characteristics and the cost/return of the commercial pullet strains is vital to ensure that optimal performance can be achieved. Also, for good management and economic decisions, it is wise to know the short-term comparative performance of different breeds so that stockholders do not have to wait till the end of laying before taking major decisions as to the profitability or otherwise of the layer strain on their farm.

This study was, therefore, carried out to examine the place of genetic composition in the growth, nutrient utilization and cost/benefit values of pullets fed with the same feed under the same condition.

\section{Materials and methods}

This study was carried out in the Pullet house at the Teaching and Research Farm of the University of Ibadan, Ibadan, Nigeria, from January to April, 2002. Ibadan is geographically located between latitude $7^{\circ} 20^{\prime} \mathrm{N}$ and longitude $3^{\circ} 50^{\prime} \mathrm{E}$ at an altitude of $200 \mathrm{~m}$. The experiment was carried out to compare the growth performance of Bovans Nera with three other commercial pullet strains, Bovans Godline, Lohmann White and Lohmann Tradition. They are exotic strains from Germany and United States of America but hatched in Nigeria. The house was partitioned into four experimental pens, each of which was demarcated and labelled $\mathrm{A}_{1}, \mathrm{~A}_{2}$, and $\mathrm{A}_{3}$ for Bovans Nera; $\mathrm{B}_{1}$, $\mathrm{B}_{2}$ and $\mathrm{B}_{3}$ for Bovans Godline; $\mathrm{C}_{1}, \mathrm{C}_{2}$, and $\mathrm{C}_{3}$ for Lohmann White; and $\mathrm{D}_{1}, \mathrm{D}_{2}$, and $\mathrm{D}_{3}$ for Lohmann Tradition each housing twelve birds per strain. The percentage mortality of the four strains of pullet birds raised in the same environment was $1.961 \%$ for Lohmann White, Bovans Nera and Lohmann Tradition but 2.445\% for Bovans Goldline strain. The pens thus had 10 birds each. The chicks were subjected to the same treatment and fed ad-libitum with four diet, chick mash in two diet of four weeks each, growers mash $\left(9-17^{\text {th }}\right.$ week) and layers mash (18-20 th week) while light was provided at night throughout the period of the experiment lasted for 20 weeks. The diets were respectively with the following composition:

\section{Starter mash}

Diet 1: Crude protein $=20.23 \%$ and metabolizable energy of $2680 \mathrm{Kcal} / \mathrm{Kg}$

Diet 2: Crude protein $=20.48 \%$ and metabolizable energy of $2780 \mathrm{Kcal} / \mathrm{Kg}$

Growers mash: Crude protein $=16.00 \%$ and metabolizable energy of $2685 \mathrm{Kcal} / \mathrm{Kg}$

\section{Layers mash}

At day-old, the chicks were given anti-stress and glucose in their drinking water up to the day three, and intraoccular Newcastle disease vaccine (NDU) at day 2. From day five, anti-bacteria drug (Neoceryl plus), gumboro vaccine at day 12 and coccidiostats (Amproteum) for 6-days from $19^{\text {th }}$ day. The birds were also vaccinated against fowl pox at the $9^{\text {th }}$ week, against Newcastle disease at $14^{\text {th }}$ week and lasota at $23^{\text {rd }}$ week. The initial weights of the chicks were taken before the commencement of the study and subsequently every week. Other records collected for the chick study include feed intake, live weight and live weight gain which were measured weekly. Costs and returns were recorded to enable net returns per bird to be determined. Data were collected also on feed consumption, total feed consumed per strain for each period, cost of day-old chicks, cost of feeding and transportation of strains, feed efficiency and feed conversion ratio. All data collected were subjected to the analysis of variance using the SAS (1999) General Linear Model procedure (GLM). Differences between treatment means were separated using Duncans New Multiple Range Test (Duncan, 1955). Profitability was assessed using net returns by subtracting costs (rearing pullet, feed and packaging excluding overheads and labour) from income (from egg sales and spent birds).

\section{Results and discussion}

The average feed intake at week 4, between strains was statistically different at $5 \%$ level of significance (Tab. 1). The average feed intake of the birds was influenced by the strain difference with Lohman Tradition having the highest ( $548.69 \pm 2.57 \mathrm{~g}$ per bird) feed intake, followed by Bovans Nera (514.88 \pm 3.93 g per bird) while Bovans Goldline had the lowest $(436.11 \pm 0.09 \mathrm{~g}$ per bird). However, at week 10 , 12,16 and 20 , the average feed intake of the birds was still influenced by strain differences with Bovans Nera still having the highest $(2712.00 \pm 17.25 \mathrm{~g} / \mathrm{bird}, 3762.22 \pm 20.85 \mathrm{~g} /$ bird, $6539.33 \pm 15.96 \mathrm{~g} / \mathrm{bird}$ and $9243.00 \pm 22.03 \mathrm{~g} / \mathrm{bird}$ ) 
Tab. 1. Average feed intake of growing pullet strain on same diet

\begin{tabular}{ccccc}
\hline Period (week) & Bovans Goldline & Lohman White & Lohman Tradition & Bovans Nera \\
\hline 4 & $436.11 \pm 0.90^{\mathrm{d}}$ & $472.19 \pm 1.53^{\mathrm{c}}$ & $548.69 \pm 2.57^{\mathrm{a}}$ & $514.88 \pm 3.93^{\mathrm{b}}$ \\
\hline 8 & $1682.51 \pm 7.16^{\mathrm{b}}$ & $1673.76 \pm 8.62^{\mathrm{b}}$ & $1847.28 \pm 8.39^{\mathrm{a}}$ & $1846.23 \pm 2.84^{\mathrm{a}}$ \\
10 & $2450.54 \pm 17.39^{\mathrm{c}}$ & $2386.86 \pm 14.00^{\mathrm{d}}$ & $2629.16 \pm 18.16^{\mathrm{b}}$ & $2712.00 \pm 17.25^{\mathrm{a}}$ \\
12 & $3396.78 \pm 13.66^{\mathrm{c}}$ & $3328.69 \pm 19.42^{\mathrm{d}}$ & $3636.48 \pm 24.06^{\mathrm{b}}$ & $3762.22 \pm 20.85^{\mathrm{a}}$ \\
16 & $6096.33 \pm 8.86^{\mathrm{c}}$ & $5948.80 \pm 26.12^{\mathrm{d}}$ & $6455.96 \pm 25.46^{\mathrm{b}}$ & $6539.33 \pm 15.96^{\mathrm{a}}$ \\
\hline 20 & $8815.02 \pm 16.29^{\mathrm{c}}$ & $8539.33 \pm 36.11^{\mathrm{d}}$ & $9138.48 \pm 38.81^{\mathrm{b}}$ & $9243.00 \pm 22.03^{\mathrm{a}}$ \\
\hline
\end{tabular}

Means with different superscript in the same row are significantly different

feed intake but Lohmann white having the lowest (2386.86 $\pm 14.00 \mathrm{~g} / \mathrm{bird}, 3328.69 \pm 19.42 \mathrm{~g} / \mathrm{bird}, 5948.80 \pm 26.12 \mathrm{~g} /$ bird and $8539.33 \pm 36.11 \mathrm{~g} / \mathrm{bird})$ respectively during the period (Tab. 1).

This suggests that Bovans Nera consume more feed on average than the other strains of pullets. This agrees with Yakubu et. al (2007). This difference in feed consumption can be attributed to variation in the genetic constitution of individual strains.

The feed conversion ratio of the strains of pullet was statistically significant for the different weeks except at week 10 where it was not statistically significant among the Bovans, Goldline, Lohmann white and Lohmann Tradition at $5 \%$ level of significance (Tab. 2). At week 4 , the feed conversion ratio for Bovans Goldline was highest $(8.856 \pm 0.215)$, followed by Lohmann white (6.151 \pm 0.112$)$. At weeks 8, 10, 12, 16 and 20, Lohmann Tradition had the highest feed conversion ratio of $5.433 \pm 0.196,5.927 \pm 0.177 \mathrm{~g} / \mathrm{kg}$, $6.064 \pm 0.179,6.565 \pm 0.182$ and $7.001 \pm 0.134$ respectively while Bovans Nera had the lowest feed conversion ratio of $4.446 \pm 0.141,4.830 \pm 0.136,4.980 \pm 0.156,5.599 \pm 0.097$ and $6.098 \pm 0.880$ respectively for the same periods (Tab. 2).

This suggests that, Bovans Nera strain of pullets are the most efficient in feed conversion to body weight, and thus will cost less to produce equal weight of Bovans Neras than the other strains of pullets although with the lowest variability. However, feed conversion ratio increased with age at different growing period for the different strain but with Bovans nera having the largest increase on average.

This is an indication of more unit of feed consumption per unit weight gain for Bovan Nera. Bovans nera appears to be the best among the strain in terms of the feed conversion ratio.

Tab. 2. Feed conversion ratio of growing pullet strains of birds fed the same diet

\begin{tabular}{ccccc}
\hline $\begin{array}{c}\text { Period } \\
\text { (week) }\end{array}$ & $\begin{array}{c}\text { Bovans } \\
\text { Goldline }\end{array}$ & $\begin{array}{c}\text { Lohman } \\
\text { White }\end{array}$ & $\begin{array}{c}\text { Lohman } \\
\text { Tradition }\end{array}$ & $\begin{array}{c}\text { Bovans } \\
\text { Nera }\end{array}$ \\
\hline 4 & $8.956 \pm 0.215^{\mathrm{a}}$ & $6.151 \pm 0.112^{\mathrm{d}}$ & $7.743 \pm 0.101^{\mathrm{b}}$ & $7.056 \pm 0.133^{\mathrm{c}}$ \\
8 & $4.964 \pm 0.246^{\mathrm{ab}}$ & $5.215+0.200^{\mathrm{a}}$ & $5.433+0.196^{\mathrm{a}}$ & $4.446+0.141^{\mathrm{b}}$ \\
10 & $5.622 \pm 0.222^{\mathrm{a}}$ & $5.719 \pm 0.185^{\mathrm{a}}$ & $5.927 \pm 0.177^{\mathrm{a}}$ & $4.830 \pm 0.138^{\mathrm{b}}$ \\
12 & $5.312 \pm 0.208 \mathrm{~b}^{\mathrm{c}}$ & $5.681 \pm 0.194^{\mathrm{a}}$ & $6.064 \pm 0.179^{\mathrm{a}}$ & $4.980 \pm 0.156^{\mathrm{c}}$ \\
16 & $6.012 \pm 0.200^{\mathrm{bc}}$ & $6.140 \pm 0.130^{\mathrm{ab}}$ & $6.565 \pm 0.182^{\mathrm{a}}$ & $5.599 \pm 0.097^{\mathrm{c}}$ \\
20 & $6.533 \pm 0.140^{\mathrm{b}}$ & $6.748 \pm 0.133^{\mathrm{ab}}$ & $7.001 \pm 0.134^{\mathrm{a}}$ & $6.098 \pm 0.880^{\mathrm{c}}$ \\
\hline \multicolumn{5}{l}{ Means with different superscript in the same row are significantly different }
\end{tabular}

Tab. 3 shows the pooled data result of the average feed efficiency of growing pullet strains of commercial birds fed with the same diet. Except at week 10, there was no significant difference in the feed efficiency among Bovans Goldline, Lohmann White and Lohmann Tradition at 5\% level of significance, feed efficiency of the commercial birds was statistically significant at $5 \%$ level between the four strains of pullet birds. At week 4, Lohmann White had the highest feed efficiency $(0.165 \pm 0.003)$ followed by Bovans Nera $(0.143 \pm 0.003 \mathrm{~kg} / \mathrm{g}$ feed) while Lohmann Tradition had the smallest $(0.131 \pm 0.002)$. Subsequently, at week 8, 10, 12, 16 and 20, Bovans Nera had the highest feed efficiency of $0.228 \pm 0.008,0.212 \pm 0.006,0.206 \pm 0.006,0.180 \pm 0.003$ and $0.165 \pm 0.002$ respectively.

This indicates a greater weight gain per unit feed intake by Bovans Nera compared with the other strains of pullet birds. The smallest feed efficiency was recorded for Lohmann Tradition from week 10 to the last period.

The result suggests that there was better nutrient utilization of the feed consumed for body maintenance and growth by Bovans Nera when compared with the other strains. This agrees with Olawumi and Dudusola (2012), and Yakubu et. al (2007) who reported that Bovans Nera genotypes are more feed efficient and converted feeds given to produce more eggs than the other strain under the same condition The only explanation for this difference can be attributed to genotype variability.

The average live weights of the growing Bovans Nera strain were identical and compared favourably with each other except in period 0 and 4 as there was no significant different between the live weights for period 8,10 , 12, 16 and 20 (Tab. 4). The same trend applied to Bovans Goldline. However, the live weights between pullet strains were statistically significant at $5 \%$ of significance at

Tab. 3. Feed efficiency of growing pullets strains on the same diet

\begin{tabular}{ccccc}
\hline $\begin{array}{c}\text { Period } \\
\text { (week) }\end{array}$ & $\begin{array}{c}\text { Bovans } \\
\text { Goldline }\end{array}$ & $\begin{array}{c}\text { Lohman } \\
\text { White }\end{array}$ & $\begin{array}{c}\text { Lohman } \\
\text { Tradition }\end{array}$ & $\begin{array}{c}\text { Bovans } \\
\text { Nera }\end{array}$ \\
\hline 4 & $0.114 \pm 0.003^{\mathrm{d}}$ & $0.165 \pm 0.003^{\mathrm{a}}$ & $0.131 \pm 0.002^{\mathrm{c}}$ & $0.143 \pm 0.003^{\mathrm{b}}$ \\
8 & $0.213 \pm 0.009^{\mathrm{a}}$ & $0.199 \pm 0.007^{\mathrm{b}}$ & $0.192 \pm 0.007^{\mathrm{b}}$ & $0228 \pm 0.008^{\mathrm{a}}$ \\
10 & $0.185 \pm 0.006^{\mathrm{b}}$ & $0.180 \pm 0.006^{\mathrm{b}}$ & $0.173 \pm 0.005^{\mathrm{b}}$ & $0.212 \pm 0.006^{\mathrm{a}}$ \\
12 & $0.196 \pm 0.007^{\mathrm{b}}$ & $0.182 \pm 0.006^{\mathrm{bc}}$ & $0.169 \pm 0.005^{\mathrm{b}}$ & $0.206 \pm 0.006^{\mathrm{a}}$ \\
16 & $0.171 \pm 0.005^{\mathrm{ab}}$ & $0.0165 \pm 0.004^{\mathrm{bc}}$ & $0.157 \pm 0.004^{\mathrm{c}}$ & $0.180 \pm 0.003^{\mathrm{a}}$ \\
20 & $0.155 \pm 0.003^{\mathrm{b}}$ & $0.150 \pm 0.003^{\mathrm{bc}}$ & $0.144 \pm 0.003^{\mathrm{c}}$ & $0.165 \pm 0.002^{\mathrm{a}}$ \\
\hline
\end{tabular}

Means with different superscript in the same row are significantly different 
Tab. 4. Average live weight (g) of growing pullet strain fed the same diet

\begin{tabular}{ccccc}
\hline Period (week) & Bovans Goldline & Lohman White & Lohman Tradition & Bovans Nera \\
\hline 0 & $87.28 \pm 0.95^{\mathrm{a}}$ & $72.63 \pm 1.58^{\mathrm{b}}$ & $66.80 \pm 0.32^{\mathrm{c}}$ & $65.53 \pm 0.97^{\mathrm{c}}$ \\
\hline 4 & $136.73 \pm 0.93^{\mathrm{b}}$ & $150.40 \pm 1.80^{\mathrm{a}}$ & $138.13 \pm 1.08^{\mathrm{b}}$ & $138.87 \pm 1.11^{\mathrm{b}}$ \\
\hline 8 & $443.83 \pm 14.83^{\mathrm{b}}$ & $406.67 \pm 12.63^{\mathrm{b}}$ & $419.93 \pm 12.95^{\mathrm{b}}$ & $493.33 \pm 13.72^{\mathrm{a}}$ \\
10 & $540.00 \pm 15.19^{\mathrm{b}}$ & $504.50 \pm 14.41^{\mathrm{b}}$ & $522.50 \pm 13.42^{\mathrm{b}}$ & $640.83 \pm 17.47^{\mathrm{a}}$ \\
12 & $745.00 \pm 26.05^{\mathrm{b}}$ & $670.00 \pm 19.38^{\mathrm{c}}$ & $662.83 \pm 26.80^{\mathrm{c}}$ & $841.67 \pm 23.68^{\mathrm{a}}$ \\
\hline 16 & $1127.50 \pm 28.40^{\mathrm{b}}$ & $1050.00 \pm 21.97^{\mathrm{c}}$ & $1067.5 \pm 27.34^{\mathrm{bc}}$ & $1244.17 \pm 21.36^{\mathrm{a}}$ \\
\hline
\end{tabular}

Means with different superscript in the same row are significantly different

the different period. Except for period 0 and 4 when the live weights of Bovans Nera were respectively $65.53 \pm 0.97$ and $138.87 \pm 1.11$ and lower than some of the strain, it live weights were highest for period $8,10,12,16$ and 20 with values $493.33 \pm 12.72,640.83 \pm 12.47,841.67 \pm 23.68$, $1244.17 \pm 21.36$ and $1590.00 \pm 22.41$ respectively.

In addition, the variability in live weight of the Bovans Nera was lowest among the pullet strains. This suggests that, Bovans Nera will attain a greater weight and a better market value than the other pullet strains. This is in contradiction with Yakubu et al. (2007) who reported that Lohmann Brown hens had significantly higher body weight compared with others. The differences between the two studies might be due to differences in age of birds, management and other environmental conditions which vary from one location to another. The differences observed between these strains examined at different growing periods may be adjudged to be genetic, since body weight has been reported to be the most frequently used indicators of cumulative growth (Chambers, 1990) and to

Tab. 5. Profitability analysis of the strains of birds

\begin{tabular}{|c|c|c|c|c|c|c|c|c|}
\hline Strain & $\begin{array}{l}\text { Period } \\
\text { (week) }\end{array}$ & Weight & Feed intake & $\begin{array}{c}\text { Feed cost/ } \\
\mathrm{Kg}\end{array}$ & $\begin{array}{c}\text { Cost of } \\
\text { feed }\end{array}$ & $\begin{array}{c}\text { Cost of } \\
\text { medication }\end{array}$ & Total cost & Net returns \\
\hline \multirow[t]{7}{*}{ Bovans Goldline } & 4 & 0.398 & 0.436 & 32.43 & 14.14 & 10.87 & 294.97 & \\
\hline & 8 & 0.438 & 1.246 & 35.49 & 44.22 & 7.30 & 346.49 & \\
\hline & 10 & 0.545 & 0.768 & 31.71 & 24.35 & 1.71 & 372.55 & \\
\hline & 12 & 0.690 & 0.946 & 31.71 & 30.00 & 3.82 & 406.37 & \\
\hline & 16 & 0.777 & 2.700 & 31.71 & 85.62 & 1.84 & 493.83 & \\
\hline & 20 & 2.157 & 2.717 & 30.11 & 81.82 & 2.21 & 577.86 & \\
\hline & A.W & 1.714 & & & & & 2492.07 & 547.11 \\
\hline \multirow[t]{7}{*}{ Lohmann White } & 4 & 0.438 & 0.472 & 32.43 & 15.31 & 10.83 & 296.14 & \\
\hline & 8 & 0.466 & 1.202 & 35.49 & 42.66 & 7.30 & 346.10 & \\
\hline & 10 & 0.603 & 0.713 & 31.71 & 22.61 & 1.71 & 370.42 & \\
\hline & 12 & 0.734 & 0.942 & 31.71 & 29.87 & 3.82 & 404.11 & \\
\hline & 16 & 0.851 & 2.620 & 31.71 & 83.08 & 1.84 & 489.03 & \\
\hline & 20 & 1.969 & 2.591 & 30.11 & 78.02 & 2.21 & 569.26 & \\
\hline & A.W & 1.906 & & & & & 2475.06 & 353.05 \\
\hline \multirow[t]{7}{*}{ Lohmann Tradition } & 4 & 0.425 & 0.549 & 32.43 & 17.80 & 10.83 & 298.63 & \\
\hline & 8 & 0.474 & 1.299 & 35.49 & 46.10 & 7.30 & 353.03 & \\
\hline & 10 & 0.625 & 0.782 & 31.71 & 24.79 & 1.71 & 378.53 & \\
\hline & 12 & 0.724 & 1.007 & 31.71 & 31.93 & 3.82 & 414.28 & \\
\hline & 16 & 0.841 & 2.819 & 31.71 & 89.39 & 1.84 & 505.51 & \\
\hline & 20 & 2.162 & 2.683 & 30.71 & 80.79 & 2.21 & 588.51 & \\
\hline & A.W & 1.832 & & & & & 2538.49 & 499.13 \\
\hline \multirow[t]{7}{*}{ Bovans Nera } & 4 & 0.372 & 0.515 & 32.43 & 16.70 & 10.83 & 297.53 & \\
\hline & 8 & 0.409 & 1.331 & 35.49 & 47.24 & 7.30 & 352.07 & \\
\hline & 10 & 0.497 & 0.866 & 31.71 & 27.46 & 1.71 & 381.24 & \\
\hline & 12 & 0.595 & 1.050 & 31.71 & 33.30 & 3.82 & 418.36 & \\
\hline & 16 & 0.714 & 2.777 & 31.71 & 88.06 & 1.84 & 508.26 & \\
\hline & 20 & 2.143 & 2.704 & 30.11 & 81.42 & 2.22 & 591.89 & \\
\hline & A.W & 1.603 & & & & & 2549.35 & 669.74 \\
\hline
\end{tabular}

A.W is average cost per $\mathrm{Kg}$ weight 
the fact that the exotic birds were commercial hybrids that have been selected over many generations from interbreeding between specialized breeds, lines or strains. Similarly, the findings of Akinokun and Benyi (1985) support that genotype has significant effects on body weight traits.

The total cost of production per bird in Lohmann White strain for the period of 20 weeks duration of the experiment was $\$ 2475.06$ while Bovans Nera had the highest total production cost ( $\$ 2549.35)$. This was closely followed by Lohmann Tradition ( 2538.49 ) and Bovans Goldline ( 12491.07$)$. This may suggests a higher production cost for Bovans Nera when compared with other strains (Tab. 5). However, the production cost per kg live weight for Bovans Nera was the smallest (N1.60) among the pullet strains while Lohmann White had the highest one (A1.91). The cost of medication for the different pullet strains was the same for the periods except for Bovans Goldline at period $4(\mathrm{~N} 10.87)$ where had a little higher value than the others. The difference in the total cost of production was the difference in their feed intake for the different periods. This was possibly the result of the greater weight gain per unit feed intake and better nutrient utilization of the feed consumed for body maintenance and growth by Bovans Nera compared with the other strains of pullet birds. The table also shows the results of the net returns from the different strains of birds. Bovans Nera had the highest net returns ( $\$ 669.74)$, followed by Bovans Goldline (\$547.11), then Lobmann Tradition ( $\$ 499.13$ ) while Lohmann White had the lowest ( $\$ 353.05)$. Bovans Nera genotypes are therefore, more productive and profitable when compared with other genotype based on their short-term evaluation. This implies that Bovans Nera give more returns on investment even when their eggs are translated to monetary terms since it is the general belief that the higher the egg numbers of a breed of layers, the higher the net income expected from them. This is supported by Rauen et al. (1989), Spradbrow (1993), Sonaiya (1996), Alam (1997), Mallia (1999), Fattah (2000), Paul et al. (2000), Kumtakar (2000), Buza and Mwamuhehe (2001) who posited that family poultry production systems are financially economic because even if the productivity of birds is low, some poultry meat and some eggs constitute almost a net profit for poultry keepers

\section{Conclusions}

Bovans Nera is better in feed conversion ratio, feed efficiency (a greater weight gain per unit feed intake) and attains a greater weight and a better market value than $B o-$ vans Godline, Lohmann White, and Lohmann Tradition. Though, the production cost for Bovans Nera was higher when compared with other three strains, the production cost per kg live weight for Bovans Nera was least among the four strains with the highest net returns.

\section{References}

Abeke FO, Ogundipe SO, Sekoni AA, Dafwang II, Oladele SB (2003). Effects of duration of cooking of lablab (Lablab purpureus) beans on organ weights and blood parameters of pullet chicks. Proc of the $28^{\text {th }}$ Annual NSAP Conference Ibadan 28:240-242.

Agbamu JU (2005). Economic analysis of abundant Grace poultry farm at Egbokodo,Warri South Local Government area of Delta State. Proc of $10^{\text {th }}$ Annual Conference, Animal Science Association of Nigeria, September 12-15. University of AdoEkiti, Nigeria.

Akinmutimi AH (2003). Effect of processing on metabolisability of energy content of Sword beans (Canavalia gladiata) using broiler chicks (starter phase). Proc $28^{\text {th }}$ NSAP Ibadan, Nigeria 194-196 p.

Akinokun O, Benyi K (1985). The effect of genotype and housing on the laying performance of chickens in south western Nigeria. Bull Anim Health Prod Afr 33:147-151.

Alam J (1997). Impact of small holder livestock development project in some selected areas of rural Bangladesh. Livestock Res Rural Develop 9:3 http://www.lrrd.org/lrrd9/3/ bang932.htm.

Beutler A (2007). Introduction to poultry production in Saskatchewan, University of Saskatchewan, Saskatoon, Saskatchewan, S7N5A8.

Buza JJ, Mwamuhehe HA (2001). Country report: Tanzania, 38-42 p. In: Alders RG, Spradbrow PB (Eds.). SADC Planing Workshop on Newcastle Disease Control in Village Chickens. Proc No. 103, ACIAR, Canberra, Australia.

Fattah KA (2000). Poultry as a tool in poverty eradication and promotion of gender equality, 16-28 p. In: Dolberg F, Petersen PH (Eds.). Proc of a Workshop on Poultry as a Tool in Poverty Eradication and Promotion of Gender Equality. Tune, Denmark.

Hocking PM, Bain M, Channing CE, Fleming R, Wilson S (2003). Genetic variation for egg production, egg quality and bone strength in selected and traditional breeds of laying fowl. Br Poult Sci 44:365-373.

Kumtakar VA (2000). Backyard poultry system in the tribal areas Shapura Block in Jamalpur District, Madhya Pradesh, India, 136-142 p. In: Dolberg F, Petersen PH (Eds.). Proc of a Workshop on Poultry as a Tool in Poverty Eradication and Promotion of Gender Equality. Tune, Denmark.

Mallia JG (1999). Observations on farmer poultry units in parts of Central America and sustainable development opportunities. In: First INFPD/FAO Electronic Conf on the Scope and Effect of Family Poultry Research and Development.

Nawar ME, Abdou FH (1999). Analysis of heterotic gene action and maternal effects in crossbred Fayoumi Chickens. Egypt Poult Sci J 19:671-689. 
26

Oladunjoye IO, Ologhobo AD, Amao SR, Gbile AO (2005). Feeding value of raw breadfruit (Artocarpus altilis) meal for broilers. Proc of $30^{\text {th }}$ Annual Conf of NSAP $20^{\text {th }}-24^{\text {th }}$ March at University of Nsukka, Nigeria 172-174 p.

Olawumi S, Dudusola I (2012). Part-term performance traits of commercial layer strains in the derived Savannah zone of Nigeria. J Anim Sci Adv 2:332-337.

Olawumi SO, Ogunlade JT, Oseni SO, Akinokun JO (2006). Egg quality characteristics of two breeds of layer breeders in South-West Nigeria. Proc $11^{\text {th }}$ of Annual Conf of Animal Science of the Nigeria (ASAN), Sept. $18^{\text {th }}-21^{\text {th }}$. Institute of Agricultural Research and Training, Ibadan, Nigeria 249$250 \mathrm{p}$.

Olawumi SO (2007). Genotype and season interaction effects on reproductive performance of two breeds of layers in humid zone in Nigeria. Appl Tropical Agric 12:78-82.

Oluyemi JA, Roberts FA (1979). Poultry production in warm climatic. Macmillan Press Ltd, London 197 p.

Paul DC, Beg MA, Chowdhury ER, Podder CK (2000). Indigenous family chicken and its economic importance in rural Bangladesh. Proc $21^{\text {st }}$ World Poultry Congress. Montreal, Canada.

Rauen HW, Santos MDL, Fabian P (1989). Actual situation of small-scale poultry production in rural areas of Domincan Republic and improving perspective for the future. Proc on Small-Holder on Poultry Production in Developing Countries, Hemeln, Germany 113-129 p.
Sani RM, Tahir I, Kushwaha S (2000). Economics of poultry production in Bauchi State: A case study of Bauchi Local Government Area. Nig J Anim Prod 27:109-113.

Sonaiya EB (1996). Employment, income generation and skill development through rural poultry development. Proc $20^{\text {th }}$ World's Poultry Congress, New Delhi, India, 17-22 p.

Spradbrow PB (1993). Newcastle disease in village chickens. Poult Sci Rev 5:57-96.

Suk YO, Park C (2001). Effect of breed and age of hens on the yolk to albumen ratio in two different genetic stock. Poult Sci 80:855-858.

Toleun CD, Igba F (2007). Growth and carcass characteristics of broiler chickens fed water soaked and cooked velvet beans (Mucuna pruriens) meal. Proc of the $32^{\text {nd }}$ Annual NSAP Conf. Calabar, Nigeria 240-243 p.

Umeh GN, Odo BI (2002). Profitability of poultry production among school leavers in Anaocha Local Government area (LGA) of Anambra State, Nigeria. Nig J Anim Prod 29:7680.

Yakubu A, Salako AE, Ige AO (2007). Effects of genotype and housing system on the laying performance of chickens in different seasons in the Semi-Humid Tropics. Internat J Poult Sci 6:434-439. 